\title{
Hydroxyl radicals as an indicator of knocking combustion in the dual-fuel compression-ignition engine
}

The occurrence of knocking combustion is one of the basic problems of dual-fuel compression-ignition engines supplied with diesel oil and gaseous fuel. In order to detect this phenomenon and evaluate its intensity, several methods are commonly used, including the analysis of pressure of working medium in the combustion chamber of the engine or vibrations of certain engine components. This paper discusses the concept of using mass fraction of hydroxyl radicals as the indicator of the occurrence of knocking combustion. Current knowledge on the conditions of hydroxyl radical formation in the engine combustion chamber has been systematized and the results of research on this subject have been presented. Theoretical considerations are illustrated by exemplary results of simulation studies of the combustion process in a dual-fuel compression-ignition engine supplied with diesel oil and methane. The conclusions drawn may be useful for the development of dual-fuel engine control systems.

Key words: knocking combustion, dual-fuel engines, radicals, hydroxyl radicals

\section{Introduction}

Compression-ignition (CI) engines, due to their favorable durability and efficiency, have been widely used in various applications, starting from industrial stationary power generators and engineering equipment, through agriculture, and ending up in the land and marine transportation sector. The market share of vehicles equipped with CI engines is continuously rising, especially in Europe, and the current trends show that they are getting more desirable in the foreseeable future across different categories, including light, heavy-duty and off-road vehicles [36].

However, despite clear advantages of CI engines, their emissions are difficult to control by classic aftertreatment of the oxygen-rich exhaust gases through the use of catalysts $[16,31]$. Of all the substances formed in cylinders of $\mathrm{CI}$ engines, the most problematic are nitrogen oxides $\left(\mathrm{NO}_{\mathrm{x}}\right)$ and particulate matter (PM) [23]. They cause air pollution, which is linked to serious health problems, especially respiratory and cardiovascular diseases [18]. The contribution of CI engines to total air pollution has been growing as a consequence of their increasing numbers in fleets and increasing distances travelled. Moreover, even with excellent fuel economy CI engines add to the increasing intensity of consumption of natural resources. The proven oil reserves, according to various studies [1, 12], will not sufficiently meet the expected growth of worldwide demand for the upcoming years. Environmental pollution problems, increasing energy demand and depleting oil reserves, associated with the use of fossil fuels, create growing opportunities for the use of alternative fuels $[6,7]$.

In the past few decades, valuable breakthroughs in the study on combustion and emission characteristics of various fuels have been made [11] and an increasing number of CI engines have been adapted to dual-fuel mode [25]. Numerous theoretical and empirical investigations have drawn attention towards gaseous fuels, i.e. natural gas (NG) and liquefied petroleum gas (LPG), as very promising candi- dates to play the role of essential energy source in the transportation sector in the near future [16].

In comparison with other alternative fuels, NG and LPG have some distinct and desirable advantages. Both gases can be supplied to the in-use engines without significant modifications [2, 14]. The dual-fuel mode can easily be reverted back to diesel-only operation [28]. CI engines supplied with NG or LPG have good thermal efficiency at high output. Unfortunately, at part load conditions there is a drop in efficiency and power output, when compared to engine supplied with diesel oil. With respect to ecological aspects, studies have shown that the use of NG and LPG in $\mathrm{CI}$ engines results in producing less polluting exhaust gases, if appropriate conditions are satisfied for its mixing and combustion [32]. In general, the greatest benefits can be achieved from reduction of $\mathrm{NO}_{\mathrm{x}}$ and $\mathrm{PM}$ emissions. Another positive aspect of supplying CI engines with gaseous fuels is a big potential to lower noise emissions. All these advantages have prompted researchers to intensify their work on the further development of dual-fuel CI engines.

The combustion process in a dual-fuel engine is complex and combines the features of CI and spark-ignition (SI) engines [38]. Gaseous fuel, when inducted into the intake manifold or directly into the cylinder, easily mixes with fresh air and forms a homogeneous phase, which then can be ignited by a small amount of diesel oil called the pilot dose. Gaseous fuel acts as primary fuel since it is the main source of energy input to the engine. When compressed with air, it should not ignite spontaneously due to its high autoignition temperature. Diesel oil, injected near the end of compression stroke, should autoignite first and become a source of ignition for the combustion of gaseous fuel. However, if the percentage of inducted gaseous fuel is increased, the combustion process in dual-fuel engines can suffer from knocking, especially at high load [20, 21, 24, 30, 34, 42]. Knocking combustion involves autoignition of gaseous fuel-air mixture ahead of the advancing flame originated from the burning of diesel oil. Generated pressure oscilla- 
tions cause deterioration of engine efficiency, increase in exhaust emissions and engine noise [22]. Severe knock leads to excessive wear of the engine and, in extreme cases, results in damage of the engine [22].

The problem of knock is widely recognized as a major obstacle for further improvement of dual-fuel CI engines supplied with gaseous fuels. Therefore, efficient methods of knock detection and evaluation of its intensity are needed. So far, several methods have been developed [22]. In the mass-produced engines the most commonly used method of knock detection employs vibration sensors, attached to certain engine components (typically engine block or head). The main drawback of this method is the susceptibility of the vibration signal to noise, especially at large engine speed [5]. Similar problem applies to the methods of engine knock detection based on direct measurement and analysis of in-cylinder pressure. In this case however, the fact of autoignition cyclic variability, even at the same in-cylinder pressure, must be taken into account [4]. One of the promising techniques used in engine knock detection involves determination of the quantity (e.g. mass fraction) of radicals existing in the in the combustion chamber $[3,15,17,19$, $26,27,29,33,37,40]$. In order to acquire information about the quantity of radicals, chemical luminescence methods are widely used [3, 15, 17, 19, 29, 33, 37].

The focus of this paper is to discuss the mass fraction of hydroxyl radicals as an indicator of knocking combustion in the dual-fuel CI engine. Current state of the research on this issue has been reviewed and the results of simple simulations of the combustion process in dual-fuel CI engine, with particular emphasis on hydroxyl radicals formation, have been presented.

\section{Hydroxyl radicals as an indicator of knocking combustion}

The oxidation of hydrocarbon fuel in engine combustion chamber involves a variety of intermediate compounds, which reactions, in ideal conditions, lead to the final products, i.e. carbon dioxide $\left(\mathrm{CO}_{2}\right)$ and water $\left(\mathrm{H}_{2} \mathrm{O}\right)$ [27]. The whole process is known to develop through a complex radical chain mechanism. The significant feature of this mechanism is branching of the chain, which makes combustion easy to self-accelerate, especially if intensified by the exothermic character of reaction. The autoignition of organic substances is strongly related to their exothermic oxidation chemistry, but the specific course of reaction is determined by the physical properties of the environment within which it takes place. The majority of alkanes follow a mechanism of oxidation, which is presented in Figure 1.

Complete mechanisms, which determine the existence of specific substances, have not been fully recognized yet, but the most important chemical reactions have been identified $[10,13,29]$. Initiation step of the mechanism of alkane oxidation, can be triggered by molecular oxygen $\left(\mathrm{O}_{2}\right)$, hydroxyl radical $(\mathrm{OH})$ or hydroperoxyl radical $\left(\mathrm{HO}_{2}\right)$ according to the following reaction [27]:

$$
\mathrm{RH}+\mathrm{O}_{2} / \mathrm{OH} / \mathrm{HO}_{2} \rightarrow \mathrm{R}+\mathrm{HO}_{2} / \mathrm{H}_{2} \mathrm{O} / \mathrm{H}_{2} \mathrm{O}_{2}
$$

Subsequent stages of alkane combustion involve large number of other radicals, e.g. hydridocarbon $(\mathrm{CH})$, hydridooxidocarbon (HCO) and formaldehyde radical (HCHO) [29]. They have been identified as markers of different combustion phases, what makes it possible to detect engine knock based on intermediate radicals analysis [41].

As can be seen from previous studies, even though most of them concern SI engines, the concentration or mass fraction of hydroxyl radicals is found to be good indicator of knocking combustion. Shoji et al. [33] analyzed chemical luminescence emission of hydroxyl and other radicals inside engine cylinder. Under knocking combustion, hydroxyl radicals emerged earlier compared to normal combustion, and their quantity increased up to the occurrence of autoignition. Kawahara et al. [19] found that the fluctuations of hydroxyl radical emission intensity is synchronized with the in-cylinder pressure fluctuations (Fig. 2). Zhen et al. [40] observed that the changes of hydroxyl radical quantity were virtually the same with the changes of temperature. They stated that hydroxyl radicals play a major role during the transition from low-temperature chemistry to hightemperature autoignition. Merola and Vaglieco [26] proved that hydroxyl radicals were detected and correlated to the onset and the duration of knocking combustion. In the research of Azimov et al. [3], hydroxyl radicals emission intensity was evaluated as strong for knocking combustion cycles while in conventional combustion it could barely be detected. A similar conclusions were reached by Hashimoto et al. [15] and Itoh et al. [17], who reported that under nonknocking conditions hydroxyl radicals show relatively weak emission intensities, but for autoignition and knocking cycles these intensities gradually increase, compared to conventional cycle.

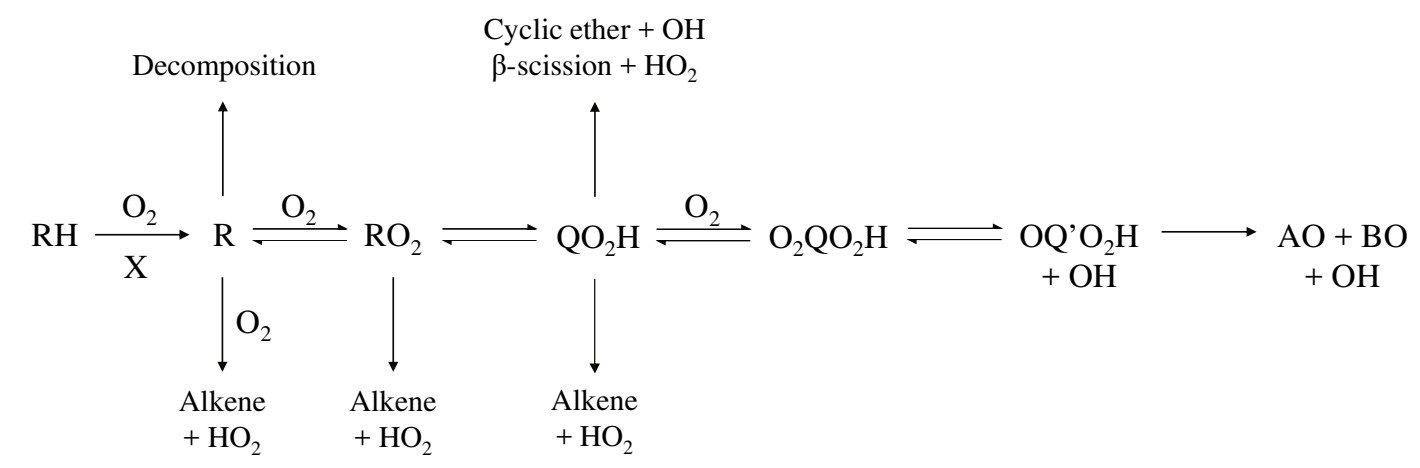

Fig. 1. Mechanism of alkane oxidation: $\mathrm{RH}$ - alkane, $\mathrm{R}$ - alkyl radical, $\mathrm{OH}$ - hydroxyl radical, $\mathrm{HO}_{2}$ - hydroperoxy radical, $\mathrm{X}$ - various radicals, $\mathrm{AO}$, $\mathrm{BO}-$ molecular oxygenated species [27] 


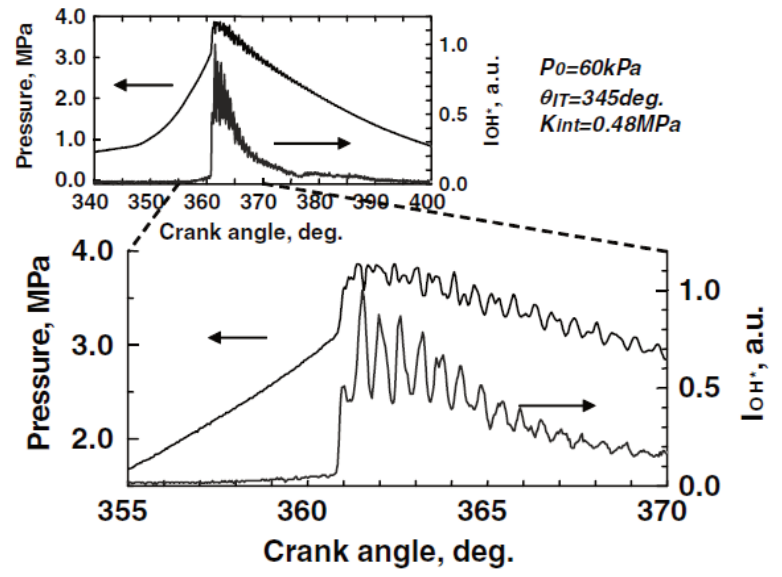

Fig. 2. Oscillation of the hydroxyl radical emission intensity $-\mathrm{I}_{\mathrm{OH}}$. with the in-cylinder pressure [19]

\section{Simulation of hydroxyl radicals formation during combustion in a dual-fuel engine}

\subsection{Model assumptions}

As an example of the dependence of mass fraction of hydroxyl radical on engine operating conditions, simulation of the combustion process in a dual-fuel CI engine supplied with diesel oil and methane was performed. Numerical analysis was carried out using a one-dimensional model, developed in AVL BOOST software. The model was parametrized based on the specifications of Cummins B6-T590 engine (Table 1) and validated by comparison with empirically determined data.

Table 1. Specifications of Cummins B6-T590 engine [8, 9]

\begin{tabular}{|l|c|}
\hline Parameter & Data \\
\hline Type & $\begin{array}{c}\text { Four-stroke, compression-ignition, } \\
\text { turbocharged, water-cooled }\end{array}$ \\
\hline Cylinder layout & In-line \\
\hline Number of cylinders & 6 \\
\hline Displacement volume & $5883 \mathrm{~cm}^{3}$ \\
\hline Bore & $120 \mathrm{~mm}$ \\
\hline Stroke & $102 \mathrm{~mm}$ \\
\hline Maximum power & $103 \mathrm{~kW} \mathrm{@}(1,700-2,200) \mathrm{rpm}$ \\
\hline Maximum torque & $565 \mathrm{~N} \cdot \mathrm{m} \mathrm{@}(1,500-1,600) \mathrm{rpm}$ \\
\hline
\end{tabular}

Fuel supply system of the engine was modified to allow the delivery of gaseous fuel to the intake manifold, while pilot dose of diesel oil was injected directly into the cylinder. The idea behind the modifications was to make the engine run in dual-fuel mode, without introducing major changes of the construction. The general structure of the engine model developed in AVL BOOST is shown in Figure 3.

The main assumption for modeling of combustion in the proposed model was the differentiation of the combustion of diesel and methane. The parameters of the working medium in the cylinder, energy-related effects and mass fractions of species were the superposition of two individual combustion processes of varying dynamics. This approach is often used in research works on the combustion process of fuels with different physicochemical properties (e.g. Stelmasiak and Matyjasik [35]).

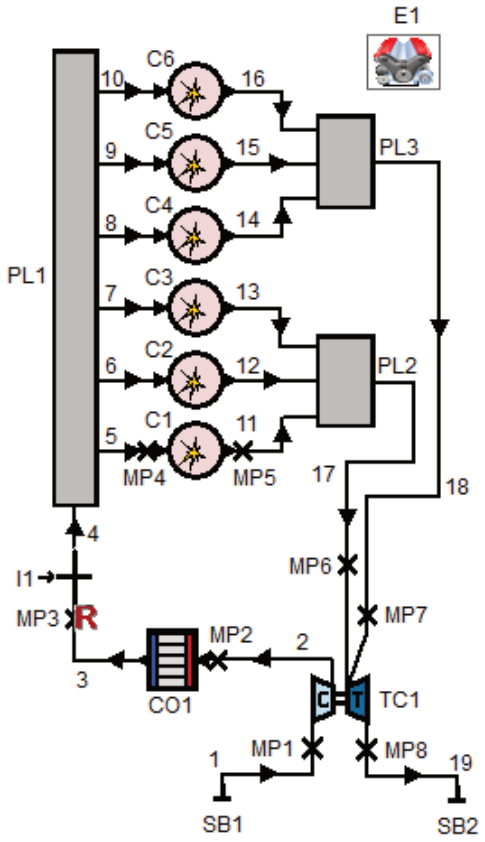

Fig. 3. The structure of the engine model developed in AVL BOOST: SB1, SB2 - system boundaries; MP1-MP8 - measuring points; TC1 turbocharger; $\mathrm{CO} 1$ - air cooler; $\mathrm{R}$ - reference point for volumetric efficiency; I1 - gas injector; PL1-PL3 - plenums; C1-C6 - cylinders; E1 engine, $1-18$ - connecting pipes

The heat release rates were imposed by three-phase Wibe function, parametrized individually for the specific properties of methane and diesel oil. This function involves the fractions of heat for the kinetic combustion, diffusion combustion and afterburning stages, according to the general formulas [39]:

$$
\begin{gathered}
\mathrm{x}_{\mathrm{b}}=\mathrm{b}_{1} \cdot\left\{1-\exp \left[-\mathrm{a} \cdot\left(\frac{\alpha-\mathrm{SOC}}{\alpha_{\mathrm{z}}}\right)^{\mathrm{m}_{1}+1}\right]\right\}+ \\
+\mathrm{b}_{2} \cdot\left\{1-\exp \left[-\mathrm{a} \cdot\left(\frac{\alpha-\mathrm{SOC}}{\alpha_{\mathrm{z}}}\right)^{\mathrm{m}_{2}+1}\right]\right\}+ \\
+\mathrm{b}_{3} \cdot\left\{1-\exp \left[-\mathrm{a} \cdot\left(\frac{\alpha-\mathrm{SOC}}{\alpha_{\mathrm{z}}}\right)^{\mathrm{m}_{3}+1}\right]\right\} \\
\mathrm{b}_{1}+\mathrm{b}_{2}+\mathrm{b}_{3}=1
\end{gathered}
$$

where: $\alpha$-crank angle, SOC - crank angle corresponding to the start of combustion, $\alpha_{z}-$ crank angle corresponding to combustion duration, a - completeness of combustion (for complete combustion $a=6.908$ ), $b_{1}-$ mass fraction burnt coefficient for kinetic combustion, $\mathrm{b}_{2}-$ mass fraction burnt coefficient for diffusion combustion, $b_{3}-$ mass fraction burnt coefficient for afterburning, $\mathrm{m}_{1}$ - combustion rate for kinetic combustion, $\mathrm{m}_{2}-$ combustion rate for diffusion combustion, $\mathrm{m}_{3}-$ combustion rate for afterburning.

The crank angle corresponding to combustion duration $\left(\alpha_{z}\right)$, coefficients for mass fraction burnt $\left(b_{1}-b_{3}\right)$ and combustion rates $\left(\mathrm{m}_{1}-\mathrm{m}_{3}\right)$ were assumed separately for each fuel. The angle of the start of combustion, the same for both fuels, was determined by autoignition delay angle of diesel oil. The angles of the end of combustion of diesel and methane were different and set arbitrarily. The variables used 
in the model allow independent simulation of the course of heat generation, separately for diesel oil and methane.

\subsection{Model validation}

The validation of the model was accomplished by comparing the simulated course of pressure of the medium inside the cylinder with the pressure measured empirically on the engine test bed. The empirical data used for model validation was obtained by the research team of Kruczyński et al. at Institute of Vehicles of Warsaw University of Technology. The data was published in papers $[20,21]$, where detailed conditions of the tests have been described.

The comparison was made for the same engine working conditions, defined by engine speed and load, with diesel oil, methane and air consumption as well as the parameters of the working medium introduced to the model. The independent variable parameters were described in section 3.1 of this paper. Their values were modified in order to ensure that the simulated course of pressure was sufficiently close to the measured one. Sample results of the comparison have been presented in Figure 4. They refer to engine speed of $1800 \mathrm{rpm}$, maximum load and two modes of fuel supply: single-fuel, with diesel oil only, and dual-fuel, with a mixture of diesel oil and 30\% (w/w) of methane. The crankshaft rotation angle of $0 \mathrm{deg}$ corresponds to the Top Dead Centre.
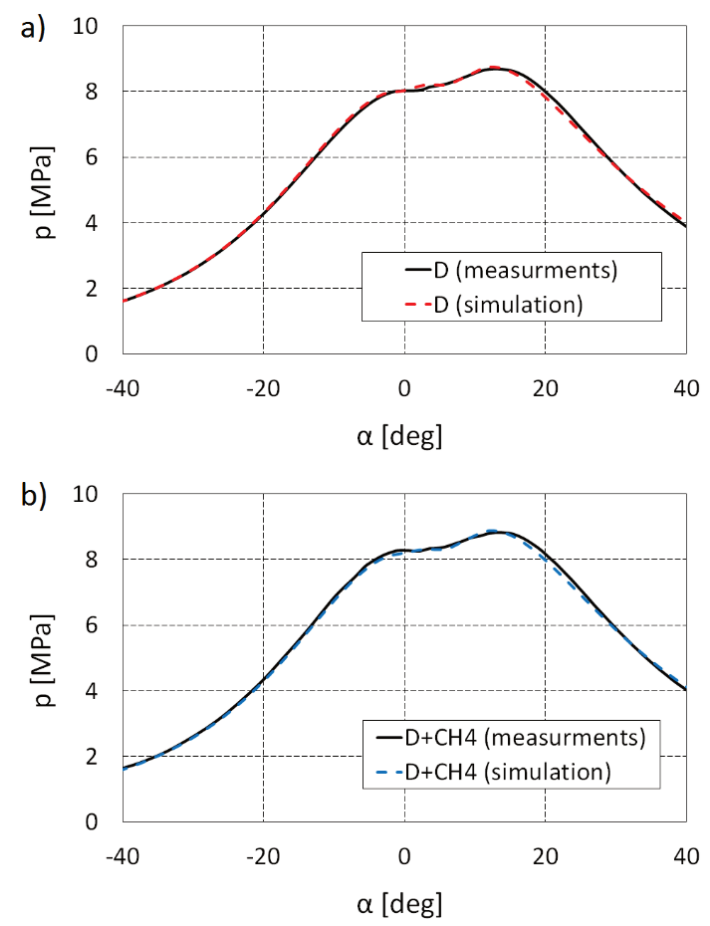

Fig. 4. Comparison of the pressure simulated and measured empirically (engine speed $1800 \mathrm{rpm}$, maximum load) for two cases of engine supply: a) with diesel oil - D, b) with a mixture of diesel oil and $30 \%(w / w)$ of methane $-\mathrm{D}+\mathrm{CH} 4$

The comparison of the course of pressure has shown a sufficient conformity in all analyzed points. However, for a more in-depth assessment of the accuracy of the estimation of measured in-cylinder pressure by the model, absolute and relative errors have been calculated using the following formulas:

$$
\Delta \mathrm{p}=\mathrm{p}_{\mathrm{m}}-\mathrm{p}_{\mathrm{s}}
$$

$$
\delta \mathrm{p}=\left(\mathrm{p}_{\mathrm{m}}-\mathrm{p}_{\mathrm{s}}\right) / \mathrm{p}_{\mathrm{m}}
$$

where: $\Delta \mathrm{p}$ - absolute error, $\delta \mathrm{p}$ - relative error, $\mathrm{p}_{\mathrm{m}}-$ measured in-cylinder pressure, $\mathrm{p}_{\mathrm{s}}-$ simulated in-cylinder pressure.

Example error values, calculated for the pressure presented in Figs 4a and 4b, are shown in Fig. 5. Generally, for both engine supply modes, the absolute and relative errors can be rated as not large - their values do not exceed the range of $(-0.15-0.2) \mathrm{MPa}$ and $(-3.0-3.0) \%$ respectively. The smallest errors occur within the crankshaft angle corresponding to the compression stroke, while the largest follow active combustion and relate to the cylinder pressure drop. The analysis of absolute and relative errors confirms good quality of estimation of measured pressure by the developed model.
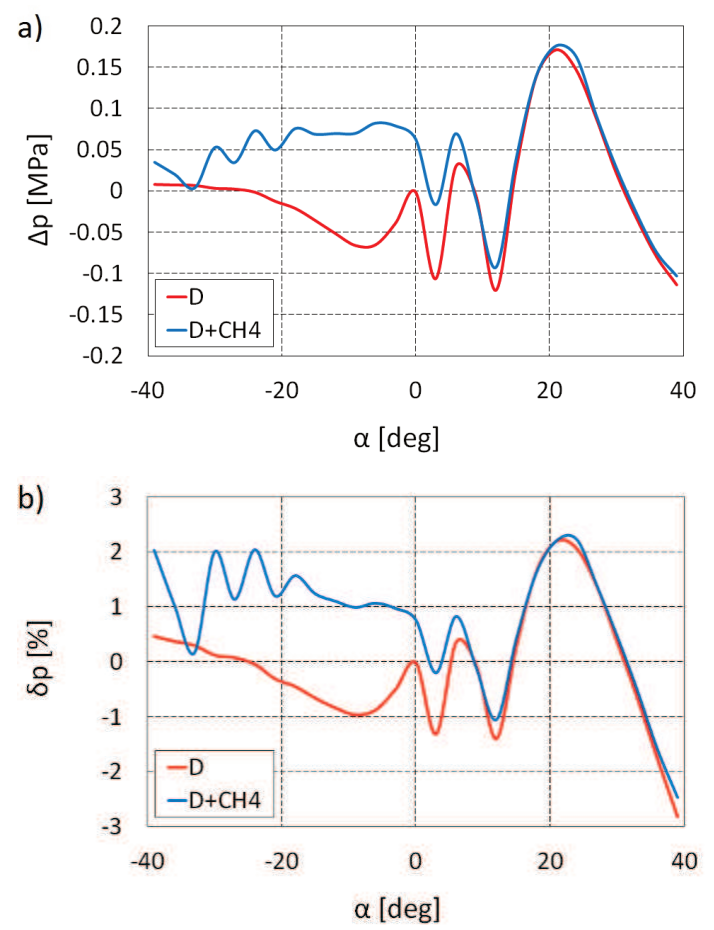

Fig. 5. Absolute (a) and relative (b) errors of the accuracy of the estimation of measured in-cylinder pressure by the model for two cases of engine supply with diesel oil - D and with a mixture of diesel oil and $30 \%(w / w)$ of methane $-\mathrm{D}+\mathrm{CH} 4$

\subsection{Simulation results and discussion}

AVL BOOST contains a general species transport model, which allows the implementation of a kinetic model. The software solves species transport equations for an arbitrary number of chemical species. In this simulation, default kinetic model was extended to enable determination of hydroxyl radicals mass fraction. It has been proved, that increased quantity of hydroxyl radical in the interval between the initial point of ignition and the end of combustion indicates the higher probability of knock occurrence. The aim of the simulation was to evaluate the dependence of hydroxyl radicals mass fraction on the operating conditions of the engine, determined by the following parameters: methane content in fuel, engine speed and engine load.

The influence of methane content in fuel on mass fraction of hydroxyl radicals was investigated for five cases: D100 - pure diesel oil, 20CH4 - diesel oil with $20 \%$ (w/w) 
of methane, $40 \mathrm{CH} 4$ - diesel oil with $40 \%$ (w/w) of methane, $60 \mathrm{CH} 4$ - diesel oil with $60 \%(\mathrm{w} / \mathrm{w})$ of methane and $80 \mathrm{CH} 4$ - diesel oil with $80 \%(\mathrm{w} / \mathrm{w})$ of methane. Figure 6 shows mass fraction of hydroxyl radicals obtained for engine working at $1800 \mathrm{rpm}$ and $80 \%$ of maximum load.

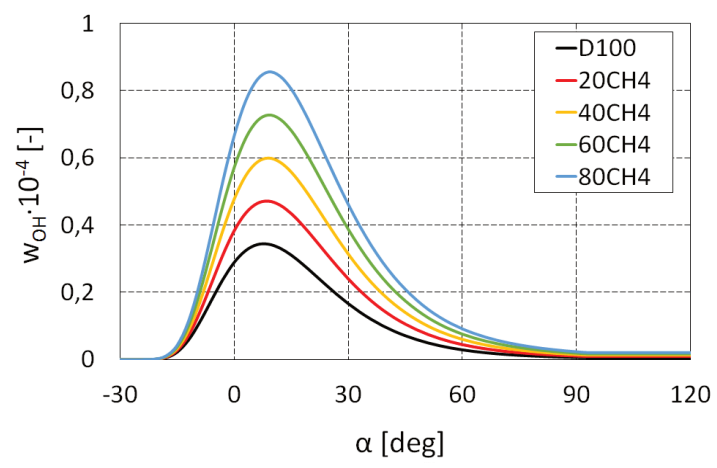

Fig. 6. Mass fraction of hydroxyl radicals $-\mathrm{W}_{\mathrm{OH}}$ for various methane content in fuel supplying the engine (engine speed $1800 \mathrm{rpm}$, engine load $80 \%)$

As shown in Fig. 6, it is clear that the increase in the mass fraction of hydroxyl radicals can be associated with an intensive combustion inside the cylinder, while the reduction is due to the ending of the combustion reaction chains. The mass fraction of hydroxyl radicals increases with the increase in methane content in engine fuel. A similar tendency can be observed for knocking intensity and methane content. According to the results of measurements performed on a test bench [21], under the same conditions of engine speed and load, knocking combustion occurred for $40 \%(\mathrm{w} / \mathrm{w})$ of methane in fuel.

The effect of engine speed on the mass fraction of hydroxyl radicals was investigated within engine speed from the range of (1200-2200) rpm with 200 rpm step. Sample results, referring to $80 \%$ of maximum engine load and $40 \%$ (w/w) of methane content in fuel, are presented in Fig. 7.

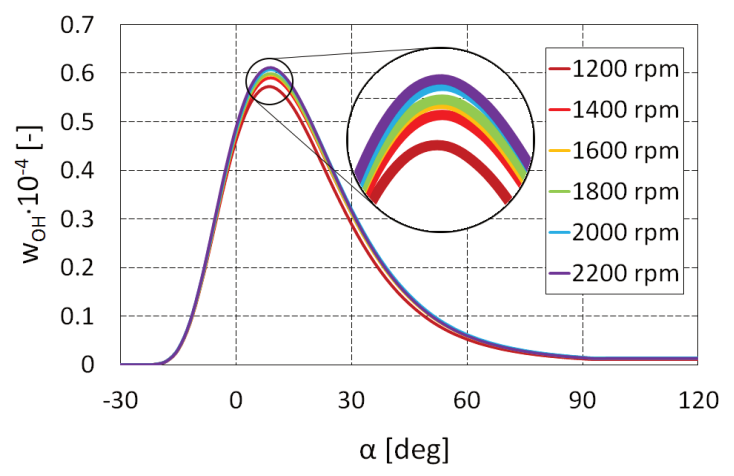

Fig. 7. Mass fraction of hydroxyl radicals $-\mathrm{W}_{\mathrm{OH}}$ for various engine speed (engine load $80 \%$, methane content in fuel $40 \%$ (w/w))

The difference in simulated mass fractions of hydroxyl radicals for various engine speed is not as significant as in the case of methane content of fuel, suggesting that the impact of engine speed on the knock is rather small. The same observation was made for all other cases of methane contents in the fuel. It should be noted, however, that the intensity of knocking in CI engines normally increases with engine speed, while in SI engines it is the other way round [42]. Dual-fuel CI engines combine the properties of both of them, and in this complex combustion process, other factors affecting knocking must be taken into account [32].

The relation between hydroxyl radical mass fraction and engine load was analyzed for $20 \%, 40 \%, 60 \%, 80 \%$ and $100 \%$ of maximum engine load, as shown in Fig. 8. The results refer to engine speed of $1800 \mathrm{rpm}$ and $40 \%(\mathrm{w} / \mathrm{w})$ methane content in the fuel.

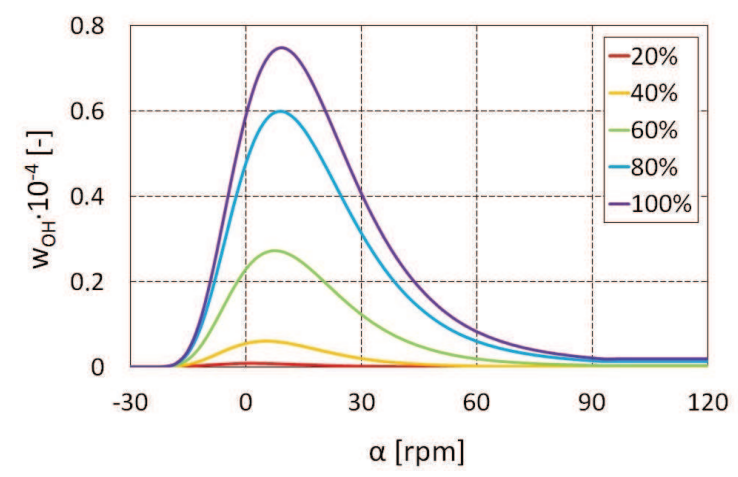

Fig. 8. Mass fraction of hydroxyl radicals $-\mathrm{W}_{\mathrm{OH}}$ for various engine load (engine speed $1800 \mathrm{rpm}$, methane content in fuel 40\% (w/w))

The impact of the engine load on hydroxyl radical mass fraction is significant. As the load increases, the mass fraction of hydroxyl radical increases. Analyzing the results shown in Fig. 8, it can be concluded that the knock probability decreases at the partial load. In the case of measurements performed on a test bench [21], under the same conditions of engine speed and methane content in fuel, knocking combustion occurred at $80 \%$ load. If the relationship between hydroxyl radical mass fraction and engine knock is considered, reduction of engine load would help to avoid knock.

Further examination of the effect of engine load includes variable content of methane in fuel. The results of the simulation, combining these two parameters, are shown in Fig. 9. The engine speed was set at $1800 \mathrm{rpm}$. Analysis of the results allows to state that engine working with $(60-$ $70) \%$ of maximum load probably would not experience knocking combustion, since hydroxyl radical mass fraction is very low, regardless methane content in fuel. For other engine speeds similar results were obtained.

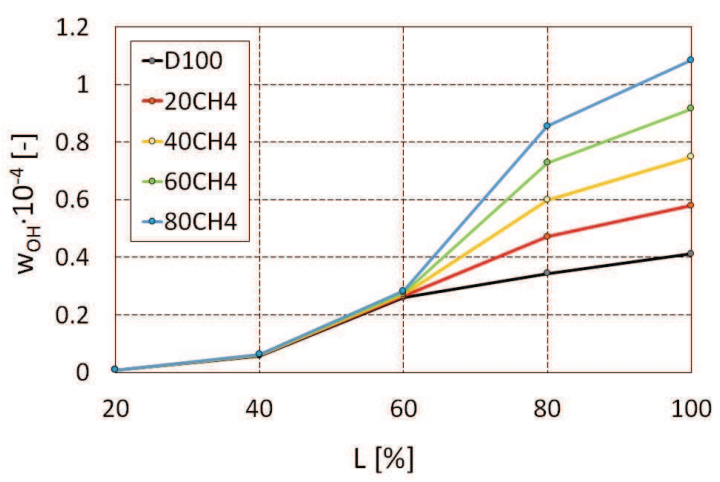

Fig. 9. The dependency of maximum hydroxyl radical mass fraction - $\mathrm{W}_{\mathrm{OH}}$ on engine relative load and methane content in fuel (engine speed $1800 \mathrm{rpm}$ ) 


\subsection{Limitations of the study}

Although the developed model has demonstrated good validity and reliability, providing sufficiently accurate estimations of the measured in-cylinder pressure in a certain dual-fuel CI engine, there are several limitations of this study that merit attention.

Like most of the engine knock simulation studies [39], this work is based on the semi-empirical model as well as simplified chemical reaction kinetics model implemented into commercial software. The implicit assumptions underlying the adopted model or simplified chemical reaction kinetics models may neglect some crucial factors determining the results of the simulation. For example, some chemical reaction species, involved in the combustion process, can be omitted. Therefore it is necessary to employ the detailed chemical reaction kinetics mechanisms to precisely investigate the autoignition mechanisms and combustion process.

Another aspect worth mentioning is the lack of quantitative dependence, of satisfactory accuracy, between knocking combustion and the mass fraction of hydroxyl radicals in engine cylinder. Previous studies have significantly contributed to general understanding of the connection between these two issues and confirmed a major role of hydroxyl radicals during knocking combustion. However, due to highly reactive and consequently short-lived nature of hydroxyl radicals, their mass fraction or concentration can be measured only in the flame zone directly in the combustion chamber [29]. Therefore the most widely used methods used to acquire information about the quantity of radicals are luminescence methods [29]. Optical emission accompanying combustion process cannot be however unequivocally identified with the quantity of radicals

In the context of the above, present study can be regarded as a preliminary work, that highlights some qualitative tendencies in terms of the relationship between mass frac- tion of hydroxyl radicals and the occurrence of knocking combustion.

\section{Conclusions}

The present state of research on the application of gaseous fuels in CI engines shows that it is one of the prominent and effective measures to overcome the crude oil scarcity and reduce exhaust emissions. While some technical aspects of dual-fuel CI engines have already reached proper degree of maturity, others are still in need for further development. Those include knocking combustion detection and evaluation. Based on a review of literature, concerning the formation of hydroxyl radicals during combustion process in engine cylinder, and results of numerical simulation of dual-fuel engine, supplied with methane and diesel oil, the following conclusions can be drawn:

- Hydroxyl radicals can act as an indicator of knocking combustion. With an increase in the mass fraction of hydroxyl radicals in the time interval between autoignition of diesel oil and the end of the combustion process, the probability of the occurrence of knock is also increasing.

- The amount of gaseous fuel, with respect to the dose of diesel oil, is a crucial factor determining the intensity of hydroxyl radicals formation in dual-fuel engine and - in consequence - the intensity of knocking combustion.

- Low to moderate load operation of dual-fuel engine restrains hydroxyl radicals formation and allow to reduce or avoid engine knock, even if gaseous fuel content is high.

- Simulation results suggest that engine speed has a minor effect on the hydroxyl radical mass fraction, despite the generally accepted fact that the effect of engine speed on the knocking combustion of conventional SI and CI engines is significant. This may mean that the developed model requires further improvements.

\section{Nomenclature}

\begin{tabular}{|c|c|c|c|}
\hline 20CH4 & diesel oil with $20 \%(\mathrm{w} / \mathrm{w})$ of methane & $\mathrm{D}$ & diesel oil \\
\hline $40 \mathrm{CH} 4$ & diesel oil with $40 \%(\mathrm{w} / \mathrm{w})$ of methane & D100 & pure diesel oil \\
\hline $60 \mathrm{CH} 4$ & diesel oil with $60 \%(\mathrm{w} / \mathrm{w})$ of methane & $\mathrm{D}+\mathrm{CH} 4$ & mixture of diesel oil and methane \\
\hline $80 \mathrm{CH} 4$ & diesel oil with $80 \%(\mathrm{w} / \mathrm{w})$ of methane & E1 & engine (AVL BOOST model) \\
\hline$\alpha$ & crank angle & $\mathrm{H}_{2} \mathrm{O}$ & water \\
\hline$\alpha_{\mathrm{z}}$ & $\begin{array}{l}\text { crank angle corresponding to combustion dura- } \\
\text { tion }\end{array}$ & $\begin{array}{l}\mathrm{HCO} \\
\mathrm{HCHO}\end{array}$ & $\begin{array}{l}\text { hydridooxidocarbon } \\
\text { formaldehyde radical }\end{array}$ \\
\hline$\Delta \mathrm{p}$ & absolute error & $\mathrm{OH}$ & hydroxyl radical \\
\hline$\delta \mathrm{p}$ & relative error & $\mathrm{HO}_{2}$ & hydroperoxyl radical \\
\hline A & completeness of combustion & I1 & gas injector (AVL BOOST model) \\
\hline $\mathrm{AO}, \mathrm{BO}$ & molecular oxygenated species & $\mathrm{I}_{\mathrm{OH}} \bullet$ & hydroxyl radical emission intensity \\
\hline$b_{1}$ & $\begin{array}{l}\text { mass fraction burnt coefficient for kinetic com- } \\
\text { bustion }\end{array}$ & $\begin{array}{l}\mathrm{L} \\
\mathrm{LPG}\end{array}$ & $\begin{array}{l}\text { engine relative load } \\
\text { liquified petrolum gas }\end{array}$ \\
\hline $\mathrm{b}_{2}$ & $\begin{array}{l}\text { mass fraction burnt coefficient for diffusion } \\
\text { combustion }\end{array}$ & $\begin{array}{l}\mathrm{m}_{1} \\
\mathrm{~m}_{2}\end{array}$ & $\begin{array}{l}\text { combustion rate for kinetic combustion } \\
\text { combustion rate for diffusion combustion }\end{array}$ \\
\hline$b_{3}$ & mass fraction burnt coefficient for afterburning & $\mathrm{m}_{3}$ & combustion rate for afterburning \\
\hline $\mathrm{C} 1-\mathrm{C} 6$ & cylinders (AVL BOOST model) & MP1-MP8 & measuring points (AVL BOOST model) \\
\hline $\mathrm{CH}$ & hydridocarbon & NG & natural gas \\
\hline $\mathrm{CI}$ & compression ignition & NOx & nitrogen oxides \\
\hline $\mathrm{CO}_{2}$ & carbon dioxide & $\mathrm{O}_{2}$ & oxygen \\
\hline $\mathrm{CO} 1$ & air cooler (AVL BOOST model) & $\mathrm{p}$ & pressure \\
\hline
\end{tabular}


PL1-PL3 plenums (AVL BOOST model)

$\mathrm{p}_{\mathrm{m}} \quad$ measured in-cylinder pressure

PM particulate matter

$\mathrm{p}_{\mathrm{s}} \quad$ simulated in-cylinder pressure

$\mathrm{R} \quad$ alkyl radical

$\mathrm{R} \quad$ reference point (AVL BOOST model)

$\mathrm{RH} \quad$ alkane

SB1, SB2 system boundaries (AVL BOOST model)
SOC

SI

$\mathrm{TC} 1$

$\mathrm{W}_{\mathrm{OH}} \quad$ mass fraction of hydroxyl radicals

$\mathrm{X} \quad$ various radicals

$\mathrm{x}_{\mathrm{b}} \quad$ heat release rate

\section{Bibliography}

[1] ABAS, N., KALAIR, A., KHAN, N. Review of fossil fuels and future energy technologies. Futures. 2015, 69, 31-49.

[2] ASHOK, B., ASHOK, S.D., KUMAR, C.R. LPG diesel dual fuel engine - a critical review. Alexandria Engineering Journal. 2015, 54, 105-126.

[3] AZIMOV, U., TOMITA, E., KAWAHARA, N. Combustion and exhaust emission characteristics of diesel micro-pilot ignited dual-fuel engine. In: Diesel engine - combustion, emissions and condition monitoring. Bari S. (Ed.). InTech, 2013.

[4] BALLAIS, R., GALLARDO-RIUZ, J.M., MEROLA, S.S. Optical diagnostics of the cycle-to-cycle variation in the kernel development and abnormal combustion: SI small engine. Journal of KONES Powertrain and Transport. 2010, 17(2), 17-25.

[5] BRECQ, G., Bellettre, J., TAZEROUT, M. A new indicator for knock detection in gas SI engines. International Journal of Thermal Sciences. 2002, 42, 523-532.

[6] CHMIELEWSKI, A., GUMIŃSKI, R., MĄCZAK, J., RADKOWSKI, S., SZULIM, P. Aspects of balanced development of RES and distributed micro cogeneration use in Poland: case study of a $\mu \mathrm{CHP}$ with Stirling engine. Renewable and Sustainable Energy Reviews. 2016, 60, 930-952.

[7] CHMIELEWSKI, A., LUBIKOWSKI, K., MĄCZAK, J., SZCZUROWSKI, K. Geometrical model of cogeneration system based on a $1 \mathrm{MW}$ gas engine. Combustion engines. 2015, 162(1), 3-10.

[8] CUMMINS. Operation and maintenance manual. Automotive, recreational vehicle, bus, and industrial 53.9 and 55.9 series engines. Cummins Engine Company, 2000.

[9] FG INSIGHT. www.fginsight.com/vip/vip/ buyers-guidecase-ih-maxxum-mx135-tractor-3174

[10] GAYDON, A.G., WOLFHARD, H.G. Flames, their structure, radiation and temperature. London, 1979.

[11] GENG, P., CAO, E., TAN, Q., WEI, L. Effects of alternative fuels on the combustion characteristics and emission products from diesel engines: A review. Renewable and Sustainable Energy Reviews. 2017, 71, 523-534.

[12] GOLDEMBERG, J., JOHANSSON, T.B., REDDY, A.K.N., WILLIAMS, R.H. Energy for the new millennium. Ambio: A Journal of the Human Environment. 2001, 30, 330-337.

[13] GRIFFITHS, J.F., WHITAKER, B.J. Thermokinetic interactions leading to knock during homogenous charge compression ignition. Combustion and Flame. 2002, 131, 386-399.

[14] HARRINGTON, J., MUNSHI, S., NEDELCU, C., OUELLETTE, P., THOMPSON, J., WHITEFIELD, S. Direct injection of natural gas in a heavy-duty diesel engine. SAE Technical Paper. 2002, 2002-01-1630.

[15] HASHIMOTO, S., AMINO, Y., YOSHIDA, K., SHOJI, H., SAIMA, A. Analysis of $\mathrm{OH}$ radical emission intensity during autoignition in a 2-stroke SI engine. In: Proceedings of the 4th COMODIA. 1998, 405-410.

[16] HEGAB, A.H., LA ROCCA, A., SHAYLER, P.J. Towards keeping diesel fuel supply and demand in balance: Dual- fuelling of diesel engines with natural gas. Renewable and Sustainable Energy Reviews. 2017, 70, 666-697.

[17] ITOH, T., NAKADA, T., TAKAGI, Y. Emission characteristics of $\mathrm{OH}$ and $\mathrm{C} 2$ radicals under engine knocking. JSME International Journal Series B. 1995, 38, 230-237.

[18] JAKUBIAK-LASOCKA, J., LASOCKI, J., SIEKMEIER, R., CHŁOPEK, Z. Impact of traffic-related air pollution on health. Advances in Experimental Medicine and Biology. 2015, 834, 21-29.

[19] KAWAHARA, N., TOMITA, E., SAKATA, Y. Autoignited kernels during knocking combustion in a sparkignition engine. Proceedings of the Combustion Institute. 2007, 31, 2999-3006.

[20] KRUCZYŃSKI, S.W., ORLIŃSKI, P., WOJS, M.K., OWCZUK, M. Ocena możliwości spalania biogazu w silniku o zapłonie samoczynnym z dawką pilotującą oleju napędowego. Zeszyty Naukowe Instytutu Pojazdów. 2014, 100(4), 103111.

[21] KRUCZYŃSKI, S.W., ORLIŃSKI, P., WOJS, M.K., OWCZUK, M., MATUSZEWSKA, A. Ocena zjawiska spalania stukowego w dwupaliwowym silniku ciągnika rolniczego zasilanego dodatkowo biogazem. Combustion Engines. 2015, 162(13), 639-646.

[22] LASOCKI, J. Engine knock detection and evaluation: a review. Zeszyty Naukowe Instytutu Pojazdów. 2016, 109(5), 41-50.

[23] LLOYD, A.C., CACKETTE, T.A. Diesel engines: environmental impact and control. Journal of the Air \& Waste Management Association. 2001, 51, 809-47.

[24] LUFT, S. A dual-fuel compression ignition engine - distinctive features. Combustion Engines. 2010, 141(2), 33-39.

[25] MATUSZEWSKA, A., OWCZUK, M., ZAMOJSKA-JAROSZEWICZ, A., JAKUBIAK-LASOCKA, J, LASOCKI, J., ORLIŃSKI, P. Evaluation of the biological methane potential of various feedstock for the production of biogas to supply agricultural tractors. Energy Conversion and Management. 2016, 125, 309-319.

[26] MEROLA, S.S., VAGLIECO, B.M. Knock investigation by flame and radical species detection in spark ignition engine for different fuels. Energy Conversion and Management. 2007, 48, 2897-2910.

[27] MOHAMED, C. Autoignition of hydrocarbons in relation to engine knock. PhD thesis. University of Leeds, 1997.

[28] PAPAGIANNAKIS, R.G., RAKOPOULOS, C.D., HOUNTALAS, D.T., RAKOPOULOS, D.C. Emission characteristics of high speed, dual fuel, compression ignition engine operating in a wide range of natural gas/diesel fuel proportions, Fuel. 2010, 89, 1397-1406.

[29] PIERNIKARSKI, D., HUNICZ, J., KOMSTA, H. Detection of knocking combustion in a spark ignition engine using optical signal from the combustion chamber. Eksploatacja $i$ Niezawodnosc - Maintenance and Reliability. 2013, 15(3), 214-220.

[30] RÓŻYCKI, A. Granica spalania stukowego w dwupaliwowym silniku o zapłonie samoczynnym. Czasopismo Tech- 
niczne z. 11. Mechanika. z. 7-M. Wydawnictwo PK, Kraków 2008.

[31] SAMOILENKO, D., CHO, H.M. Improvement of combustion efficiency and emission characteristics of IC diesel engine operating on ESC cycle applying variable geometry turbocharger (VGT) with vaneless turbine volute. International Journal of Automotive Technology. 2013, 14(4), 521528.

[32] SELIM, M.Y.E. Sensitivity of dual-fuel engine combustion and knocking limits to gaseous fuel composition. Energy Conversion and Management. 2004, 45, 411-425.

[33] SHOJI, H., SAIMA, A., SHIINO, K., IKEDA, S. Clarification of abnormal combustion in a spark ignition engine. $S A E$ Technical Paper. 1992, 922369.

[34] STELMASIAK, Z. Limitations of enrichment of gaseous mixture in dual fuel engines. Eksploatacja i NiezawodnoscMaintenance and Reliability. 2014, 16(4), 537-544.

[35] STELMASIAK, Z., MATYJASIK, M. Simulation of the combustion in a dual fuel engine with a divided pilot dose. Silniki Spalinowe. 2012, 151(4), 43-54.

[36] THE INTERNATIONAL COUNCIL ON CLEAN TRANSPORTATION (ICCT). European Vehicle Market Statistics. Pocketbook 2014 Edition.
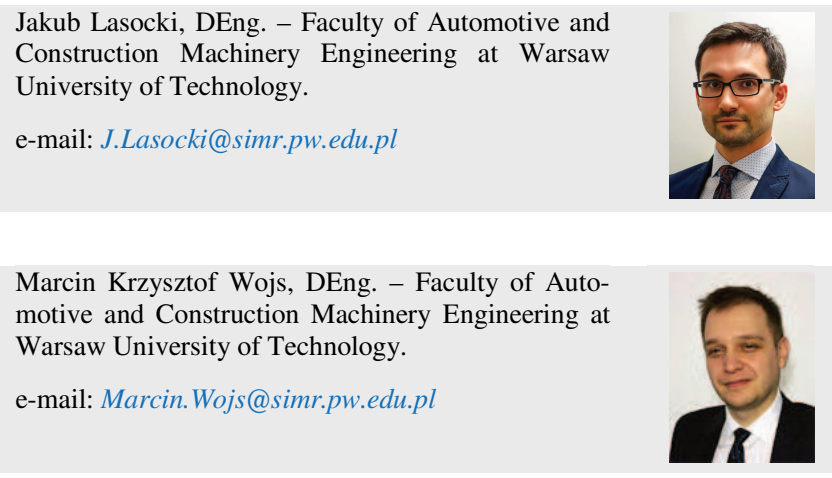

Anna Matuszewska, DEng. - Automotive Industry Institute, Department of Fuels and Renewable Energy and in Cardinal Stefan Wyszynski University.

e-mail: A.Matuszewska@pimot.eu
[37] TOSAKA, Y., SHOJI, H., SAIMA, A. A study of the influence of intermediate combustion products on knocking. JSAE Review. 1995, 16, 233-238.

[38] WAGEMAKERS, A.M.L.M., LEERMAKERS, C.A.J. Review on the effects of dual-fuel operation, using diesel and gaseous fuels, on emissions and performance. $S A E$ Technical Paper. 2012, 2012-01-0869.

[39] WIBE, I.I. Brennverlauf und Kreisprozeß von Verbrennungsmotoren (Rate of heat release in cyclic process of internal combustion engines). Verlag Technik, Berlin 1970.

[40] ZHEN, X., WANG, Y., ZHU, Y. Study of knock in a high compression ratio SI methanol engine using LES with detailed chemical kinetics. Energy Conversion and Management. 2013, 75, 523-531.

[41] ZHEN, X.D., WANG, Y., XU, S.Q., ZHU, Y.S., TAO, C.J., XU, T., SONG, M.Z. The engine knock analysis - an overview. Applied Energy. 2012, 92, 628-636.

[42] ŻÓŁTOWSKI, A. Knock combustion in dual fuel diesel engine. Journal of KONES Powertrain and Transport. 2014, 21(4), 547-553.

Piotr Orliński, DSc., DEng. - Faculty of Automotive and Construction Machinery Engineering at Warsaw University of Technology.

e-mail:P.Orlinski@simr.pw.edu.pl

Marlena Owczuk, MEng. - Automotive Industry Institute in Warsaw, Department of Fuels and Renewable Energy.

e-mail:M.Owczuk@pimot.eu
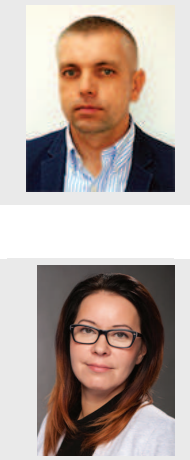

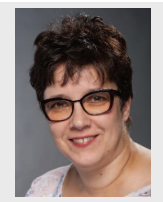

